\title{
The Implementation of Local Government's Policy Using the Waste Management Program Based on Household Needs in Bandung City
}

\author{
Emy Rachmawati, Dina Alamianti, R Indriyati Kamil, Ero Suhara, Wa Ode Nurul Yani
}

\begin{abstract}
The waste issue in Bandung city gives Bandung city "The dirtiest" and "The sea of wastes" titles. It emphasizes the importance of waste management in Bandung city as one of the biggest cities in Indonesia with a high population that produces the most massive amount of wastes. The Bandung City's government has developed a waste management policy in creating a clean environment and raising awareness on the essence of a clean environment in the society using the program's concept about waste management based on household needs. To analyse the implementation of the local government's policy using the waste management program based on household needs in Bandung city is the aim of this research. This study used the explanation method and collected its data from observations, interviews, and forms. The result of the study shows that there is a $58 \%$ of impacts between the local government's policy implementation and the effectivity of waste management based on household needs. Whilst the other impacts excluded from the study is as high as $41 \%$. Therefore, the conclusion and the analysis of the study is, there is a significant association between the implementation of the local government's policy and the effectivity of waste management based on household needs in Bandung city.
\end{abstract}

Index Terms: implementation, local government, policy, waste management.

\section{INTRODUCTION}

Waste is a big issue for many countries around the world. Most countries have a zero-waste policy, not only for hotel and restaurant but also for every household. And waste management are considered big issues because it has many implications, one of them is environmental issue. Indonesia as one of developing country have a major issue with waste management. The Government very concerned about this issue, because we produce more waste than ever, but the waste management are still inadequate. Java island have the most population than other island in Indonesia, thus it produces more waste than others, Bandung in particular.

Revised Manuscript Received on April 19, 2019.

Emy Rachmawati, Dra., M.Si., Finished my formal Education, both graduate and post graduate program in the Langlangbuana University, Bandung, Indonesia.

Dina Alamianti, S. Sos., M. I.Kom., Earned a Bachelor's in communication management at Bandung Islamic University Langlangbuana University, Bandung, Indonesia. (Email: nadien5@gmail.com)

R Indriyati Kamil, IP. M.Si., Public Administration and Communication at the University of Padjadjaran in Bandung. Work experience in survey research Langlangbuana University, Bandung, Indonesia.

Ero Suhara, S. IP, M.Si. S-1 Political Science Majors, Langlangbuana University, Bandung, Indonesia.

Wa Ode Nurul Yani, Faculty of communication sciences Padjadjaran Langlangbuana University, Bandung, Indonesia.
Bandung in the 80's known as the flower city of Indonesia, because it known for green and fresh environmental. But now it changed into big city, crowded population, traffic everywhere and worse waste management.

The waste issue in Bandung city gives Bandung city "The dirtiest" and "The sea of waste" tittles and its impact to the image of the city as tourist destination. Bandung as one of modern city in Indonesia, faced catastrophic problem of waste management. The huge problem was raised in 2005 , when the Leuwigajah landfill was collapse, hundreds of people died, consequently Bandung has no area to placed and process waste product. There were numbers of program and activity had been done to reduce waste production such as waste management program based on household needs in Bandung city.

The local government has a policy formula related to the waste management program. Bandung government regulation number 9 of 2011 about waste management process, waste divided into: organic, an-organic and dangerous and poisoning waste (article 22 (1)). The explanation of the other as follows: (1) waste is a remnant of people's daily activities from the natural process and its solid; (2) a domestic waste is a waste that came from daily activities in a household but it doesn't include specific of waste. (3) waste management is a systematic, thorough, and sustained activity that includes reduction of waste. (4) the administration of waste who handling activities was the government or the enterprising partner to organized the final processing, collection, transport, processing, and the final processing activities.

To establish a healthy and clean environment in Bandung city and also the citizens would be felt comfortable and free of pollution, it will need to waste management by all parties in an effort to make waste a resource and a mechanism. The local government of Bandung city has a Bandung government regulation number 27 of 2011 about clean/hygiene management in Bandung city and needs to be adjusted with Undang-Undang (UU) number 18 of 2008, arrangement for waste management needed legal reassurance, clarity of responsibility, regional authority, and community participation, in that case it would be worked proportionally, effectively, and sustainably. ${ }^{1}$ Bandung government regulation number 9 of 2011 verse 4 explained that the waste management based on local government regulation namely household waste, equal to household waste, and a specific waste its set further in the other of 
International Conference on Recents Advancements in Engineering and Technology (ICRAET-18) |15th and 16th March 2019|Siddhartha Institute of Technology \& Sciences, Telangana, India.

local government regulation. ${ }^{2}$ In addition to the general policy provided by RPJMD (Rencana Pembangunan Jangka Menengah Daerah) there was also instructions from the mayor of Bandung number 2 of 2013 for the action plan for the "Bandung Juara", and had been created a work group according to the duty and responsibility also personnel appointment as the activities coordinator, as for the activities associated with PD Kebersihan, and there is a "waste work group" who responsible for bring Bandung to be "Bandung Juara" in waste management.

According to the government regulation number 73 of 2005 about Kelurahan, as mentioned in article 12 (e), as a excavator, usefulness, and potential of resources development, also environment suitability, Lurah as a part of the local government was commissioned to build a socialized society and together in the environment management to create environmental cleanliness. ${ }^{3}$ Kelurahan Maleer Kecamatan Batununggal is one of the Kelurahan in Bandung city that follows the local government regulation number 9 of 2011 regarding waste management. Kelurahan Maleer is implementing the waste management program based on household needs. Kelurahan Maleer splitting into 12 RW (Rukun Warga) and RW 12 bordering with Cikapundung river, one of the longest rivers in West Java. Bordering with the river caused some problem, such as some citizens like throwing their household waste into the river, burn it, and sometimes throw it in other place. Kelurahan Maleer initiate the waste management program for society and expected to be environmentally insightful community. It's expected that the management of such refuse is in accordance with article 18 of 2008 act on waste management, chapter 12 verse 1 that everyone in the waste management based on household or equal to household is required to reduce and handle waste in an environmental way.

Among the activities carried out by the people of Kelurahan Maleer is managing organic waste from home for example compost and posturing craft from discarded waste. In addition, the non-government groups KSM (Kelompok Swadaya Masyarakat) SALING ASIH (Sadar Lingkungan Asri dan Bersih) is the one of the implementor of waste management program. There was various work in the waste management program based on household such as secondhand media plants, polybag plants via wick system methods, vertical gardens, runoff and hydroponic installations. However according to observations in the field of waste management program based on household activities implemented in Kelurahan Maleer Kecamatan Batununggal hasn't worked well as expected. This is shown by the realization of activities are describe on the table as follow:
Table I. Plan and Realization of Waste Management program based on Household in Kelurahan Maleer Kecamatan Batununggal Bandung in a year of 2017

\begin{tabular}{|c|c|c|c|}
\hline YEAR & ACTIVITY & FLAN & RENLIZATION \\
\hline \multirow[t]{5}{*}{2017} & $\begin{array}{l}\text { 1. Making flawer } \\
\text { pet fram scrap }\end{array}$ & $\begin{array}{l}\text { Every citizen using flowtr } \\
\text { scrap to muke flowerpots. }\end{array}$ & Only in RW 12 \\
\hline & $\begin{array}{l}\text { 2. Plasing troes in } \\
\text { pelybag }\end{array}$ & Every people in beir RW & Unmulalled \\
\hline & 3. Vertical Garden & $\begin{array}{l}\text { Make open green spoce in } \\
\text { Kelurahan otfice building }\end{array}$ & Accoecplished \\
\hline & $\begin{array}{l}\text { 4. Manufacture of } \\
\text { liquid znd dry } \\
\text { fertilizer }\end{array}$ & Pospic in RW & Only in RW 12 \\
\hline & 5. Glazed bricks & $\begin{array}{l}\text { Organoc maternas place in } \\
\text { RW of }\end{array}$ & Accoectphished \\
\hline
\end{tabular}

(Source Local Government in Kelurahan Maleer, 2018)

The table showed that the waste management program based on household was implemented by the nongovernmental group SALING ASIH (Sadar Lingkungan Asri dan Bersih) di Kelurahaan Maleer Kecamatan Batununggal it doesn't work properly. Its proven that not all the programs KSM SALING ASIH have planned in Kelurahan Maleer, in the reality it doesn't work properly with Undang-Undang number 18 of 2008-chapter 12 verse 1 about the waste management. The other indication that the waste management based on household in Kelurahan Maleer Kecamatan Batununggal is an ineffective because the lack of public awareness to perform duty of reducing and handling organic waste from the home in an environmental way, there is less understanding of society towards socialized media, and the lack of enthusiasm citizen participation in waste management program based on household needs.

Various indications that the waste management program based on household in Kelurahan Maleer Kecamatan Batununggal Bandung city is ineffective because their unable to accommodate the strategies and directives of policies that are pertinent with PD Kebersihan in a year of 2017. According to the assumption, it has been influenced by a variety of factors related with the policy implementation, the theoretical policy implementation as defined by Dunn is basically a practical activity that is distinguished by policy formulations. According to theoretical, implementation isn't only viewed as a form of program implementation, but also as a course of action until policy achieved.

Based on the above, it's expected to optimize the organic waste management program based on household in Kelurahan Maleer Kecamatan Batununggal Bandung which is an application from communication implementation, resources, attitudes, and bureaucracy structures. This research is trying to determine, to learn and to analyze the magnitude of local government policy implementation impact with the effectiveness of waste management program based on household needs in Bandung city (Kelurahan Maleer Kecamatan Batununggal). 


\section{LITERATURE REVIEW}

The results of this research based on provision literature are as follows:

\subsection{Policy}

Lasswell and Kaplan as quoted by Islamy that policy means as a program to achieve goals, values, and engaged actions. Based on the foregoing, its meaning are aligned with the definition of policy that quoted by Hoogerwerf, as follow, where policy is described as an attempt to reach a particular target and in a specific time order. Policy can be defined as an answer to a difficulty, and it can be defined as an attempt to solve, to diminish, or to avert a problem in a particular way of purposeful action. Based on both quote, policy can be concluded as pre-attempts problem solver in order to reduce or solve a specific problem with directional action and in a time sequence. So, policy is the action that took place step after step pointed to the pattern of action, in keeping with Solichin Abdul Wahab's view, who pointed out that the policy is a pattern of action leading to a particular goal and not simply a decision to do something.

In both views, the policy is a conscious and systematic action carried out step by step as a pattern of action leading to a particular target or goal. There are policy criteria by Dunn, namely: (1) agenda drafting is the formulation of problems that can supply relevant knowledge with policies that challenge the assumptions underlying the problem's definition; (2) policy formulation is that fortune-telling can provide relevant knowledge with policies on future issues in consequence of alternatives; (3) policy adoption leads to relevant knowledge of policies on the benefits or costs of alternative outcomes in the future have been projected through forecasting; (4) the policy assessment is the evaluation results in pertinent knowledge of the policy of discrepancy between the expected performance of the policy and actually being produced.

Based on the opinion above that the criteria laid the foundation for a policy is agenda drafting and the formulation, adoption, implementation, and also assessment on policy. Consistent with Jenkins about government policy is a sequence of related decisions that made by one or a group of political actors that related with selected goal and also ways to achieve it in a situation where the decisions remain completely within the jurisdiction of these actors.

\subsection{Government and Policy Implementation}

Government according to C.F. Strong as quoted by Pamudji is an organize power, but not always being organize by the soverign or supreme power, but government are the outcome of several people or group that prepared by an organization in order to realization of its purposes based on references.

(Presman and Widavsky (cited Tachjan) describe "implementation as to perform, accomplish, fulfill, produce, complete". Based on this agreement, implementation can be envisioned as a related activity to complete of a job with the use of means to get results. Implementation is established after legislation are recognized and gives an authority to a program, procedure, benefit, or tangible output. ${ }^{4}$ (Ripley and Franklin; cited Winarno). According to Leo, "implementation is a dynamic process, in which the policymakers perform an activity, in the end it will get a result for the policy's purpose or goal".

The definition of policy implementation according to Winarno is the implementation of a policy is seen in a broad sense, is the process from the stages of the policy immediately after the determination of the Act. So, the implementation of a widely perceived significance of implementation of legislation in which various actors, organization, procedures, and techniques work together to run the policy in an effort to achieve the goals or policies programs. The Implementation of the policy in principle is a way so that a policy can achieve its goal, nothing more and nothing less. Policy implementation is the hardest thing, because the problems are not found in the concept appears in field. In doing that, there is likely to be some aberration made by the executor of policy. That can result in a program or activity not being able to run optimally and effectively.

The implementation of policy is always exciting to be judged by either the parties involved in formulation and policy implementation or those outside the policy sphere. Increased attention to implementation of government policy is closely connected with growing awareness that government policies in many areas are less effective, especially because of problem at issue. Achieving policy objectives in practice is not what expected. It is related to obstacles both inside and outside the executive organization.

According to Edwards III suggested four (4) or variable factor is critical in the implementation of public policies, that:"communication, resources, dispositional attitude, and the structure of the bureaucracy. Due to the four factors operating simultaneously and interact with one another to help or hinder the implementation of the policies". Which of the four factors that operate simultaneously and interact to forming bonds (linkage) between the implementation of the policies and achievements will not only determine the relationship or the ideal approach between the free variables and bound variables regarding interests, but also describes the relationships between variables in achieving the success of the implementation of public policy through the following four factors: (1) Communication, In the process of communication policy there are three important things, namely transmission, consistency and clarity. Thus, was the main requirement for the implementation of an effective policy is that those who carry out the decision need to know what they should do and be transmitted to the appropriate personnel, accurate and understandable.; (2) Resources, In order for effective policy implementation, then those sources can be an important factor in implementing the policy factor, include: adequate staff, as well as a good skill to carry out their duties, authority and facilities required to translate the proposals on paper, in order to carry out the service factors i.e.: staff, information, the authority and its facilities.; (3) Dispositions or Implementing Attitude (attitude behavior tendencies) The trend of implementing 
policies is the third factor which has important consequences for the implementation of an effective policy. If the executor be kind to a certain policy, and this means the presence of support, meaning they carry out policy as expected policy makers. Because of that. It talks about the impact both positive and negative.; (4) Bureaucratic structure, the bureaucracy is one of the most frequent bodies even as a whole be executing policy. The bureaucracy is good consciously or unconsciously choose the form the form of a collective agreement for the Organization in order to solve the problem, the factors in modern life. Therefore, the bureaucratic structure is the fundamental factor to examine the implementation of the policy. However, the factor structure bureaucracy in its implementation faced two factors that allow the obstructed functions of the bureaucratic structure, i.e. the internal factors, namely the working procedures of the basic measurements (Standard Operating Procedures - SOP) and external factors, namely fragmentation. Fragmentation can be the pressures from outside the unit's bureaucracy, interest group, executive officials and other external factors.

\subsection{Waste Management}

According to Law number 8 of 2008 that in Indonesia, waste has become a national problem, and hence it is a necessity to be managed broadly, incorporated from upstream to downstream to afford economic advantage, healthy for the civic wellbeing, and safe for the environment, and change people's conduct. Based on act (UU) No.18/2008 on waste categories, waste is categorized as household waste, equal to household waste, and specific waste. Specific waste includes: waste with dangerous and poison material, dangerous and poison rubbish, waste from disaster, construction waste, unrecycled waste due to the technology, periodical waste. Generally, activities in waste management include control of rubbish pile, garbage collection, transfer, and transport, processing and final disposal. There are the stages of activity in waste management as follows; 1) Collection is considered a waste of management from home to temporary exile before going to the next stage. Trash cans, trash bins, wheelbarrows and temporary landfills were used to help. For collection, generally involves a quantity of energy that collects garbage over a given period of time. 2) The stage of transportation is done by using means of assistance in certain means of transportation to the final landfill. They also involved a force that would sometimes transport waste from a temporary exile to an end. 3) In the final stages of disposal, waste will undergo both physical, chemical and biological processing in such a way as to complete the process.

The orientation in this study on largely effectiveness and in a part ultimately depends on achieving the goal. For these points of understanding, researchers in turn, set forth the boundaries of a concept in this way: (1) the policy implementation is the formulation stage of policy and policy consequence for a society it authorizes; (2) the implementation of the local government policies about environmental hygiene program through waste management based on household needs will be optimal when it refers to four factor of public policy implementation. (3) environmental hygiene program will run effectiveness when implementing dimensions of achieving goals, integration and adaptation.

As analysis theory for effectivity variable (Y) in this study is according to Duncan (cited Steers) that explained about effectivity measurement, as follow: (1) goal achievement, is the overall effort for achieving goals must be viewed as a process; (2) integration, is a measurement to the level competence of organizations. Integration consist of procedure and socialization process; (3) adaptation, is a selfadjustment process made to align an individual with the changes that occur in the environment. Adaptation consist of ability improvement, tools and infrastructure.

\section{METHODOLOGY/MATERIALS}

\subsection{Research Methods}

Research methods used in this study is the method of empirical research information where data collected from the population, the results are then analyzed with the aim to measure the effect of one variable against other variables. This method describes the causal relationships between variable through a hypothetical test as expressed by Singarimbun, that the study describes the causal relationships between variables through hypothesis testing, then called the research explanation. The technique of data collection in this research, done through: (1) Observation, by making direct observation on the fields; (2) Interview, by making debrief with parties who understand the object of this study, such as Lurah and non-governmental group in Kelurahan Maleer Kecamatan Batununggal Bandung; 3) Questionnaires, often make use of checklist and rating scale. Each positive question was measured by Likert scale that consisted of 5 scales. The questions were developed by the researchers after reading literatures from textbooks and journals. This data collection technique is designed to determine the facts, activities, behavior and interpreters of the respondents and to dig up more comprehensive information.

\begin{tabular}{|c|c|c|}
\hline Variable & Dimension & Indicators \\
\hline \multirow{4}{*}{$\begin{array}{l}\text { Variable }(\mathbf{X}) \text { Policy } \\
\text { Implementation }\end{array}$} & Communication & $\begin{array}{l}\text { 1. Clarity of information process about the waste } \\
\text { management policy } \\
\text { 2. Socialization of waste management policies } \\
\text { 3. Consistency in information transmission of waste } \\
\text { management policy }\end{array}$ \\
\hline & Resources & $\begin{array}{ll}\text { 1. } & \text { Adequate human resources to implement waste } \\
\text { management policies } \\
\text { 2. Tool support policy enforcer } \\
\text { 3. Budgets }\end{array}$ \\
\hline & Attitudes & $\begin{array}{l}\text { 1. Executive commitment to implement waste } \\
\text { management policy } \\
\text { 2. Delegate authority }\end{array}$ \\
\hline & $\begin{array}{l}\text { Bureaucracy } \\
\text { structures }\end{array}$ & $\begin{array}{l}\text { 1. Sob descriptions to implement waste management } \\
\text { policy } \\
\text { 2. Coordination between units } \\
\text { 3. Responsibility }\end{array}$ \\
\hline \multirow{3}{*}{$\begin{array}{l}\text { Waste Management } \\
\text { Effectiveness } \\
\text { (Y) }\end{array}$} & Goal achievement & $\begin{array}{l}\text { 1. Capable of reducing and handling organic waste } \\
\text { from home in an environmentally informed way } \\
\text { 2. Achieved waste management based on household } \\
\text { needs } \\
\text { 3. Abiding by the policy of waste management }\end{array}$ \\
\hline & Integration & $\begin{array}{l}\text { 1. A society's understanding of the media used for } \\
\text { socialization } \\
\text { 2. Acclaimed targets in the community }\end{array}$ \\
\hline & Adaptation & $\begin{array}{l}\text { 1. The enthusiastic community to take a part in waste } \\
\text { management } \\
\text { 2. Improve public knowledge } \\
\text { 3. Availability of waste management tools based on } \\
\text { household needs }\end{array}$ \\
\hline
\end{tabular}


Table II showed the operational variables with the type of variables that used in this study with the dimension and indicators. Independent variable (X) is policy implementation based on the opinion of Edwards III, which specified that there are four dimensions of policy implementation. While the dependent variable (Y) that is effectivity based on the theory from Duncan (cited Steers), which explained about effectivity measurement, namely: (1) goal achievement; (2) integration; (3) adaptation.

\subsection{Population and Sample}

The determination of the respondents is based on population. The population of the region is a generalization which consisted of objects/subjects that have certain qualities and characteristics and assigned by researchers to be studied and drawn conclusions. The elements of the population in this research are local government (Kelurahan, RW), Non-government Community, and household in Kelurahan Maleer Kecamatan Batununggal Bandung as many as 121 people, that consist of (1) Local government (Kelurahan, RW) is about 24 persons; and (2) Nongovernment community and household as many as 97 persons.

\subsection{Data Analysis}

The data analysis is used regression analysis as a statistical analysis technique is to observe the independent variable effect on the dependent variable. By using regression techniques to analyze of relationships between variables, model as shown below:

$Y=a+b X$

with this additional information:

$\mathrm{Y}=$ Subject on predicted variable (effectivity)

$\mathrm{a}=$ Constant number of regressions for $\mathrm{x}=0$

$\mathrm{b}=$ Regression direct coefficient

$\mathrm{X}=$ Subject on independent variable that have certain values

In addition to above, $a$ and $b$ was calculated using the formula:

$$
\begin{aligned}
& a=\frac{\left(\sum Y i\right)\left(\sum x i^{2}\right)-\left(\sum x i\right)\left(\sum x i y i\right)}{n \sum x i^{2}-\left(\sum x\right)^{2}} \\
& b=\frac{n \sum x i y i-\left(\sum x i\right)\left(\sum y i\right)}{n \sum x i^{2}-\left(\sum x i\right)^{2}}
\end{aligned}
$$

with this additional information:

$n=$ sample

$x=$ independent variable

$y=$ dependent variable

And using the analysis of correlation regression with the formulation:

$$
r=\frac{n\left(\sum x i y i\right)-\left(\sum x i\right)\left(\sum y i\right)}{\sqrt{\left\{n\left(\sum x i^{2}\right)-\left(\sum x i\right)^{2}\right\} \cdot\left\{n\left(\sum y i^{2}\right)-\left(\sum y i\right)^{2}\right\}}}
$$

with the explanation:

$r=$ coefficient of correlation

$n=$ sample

Using coefficient of determination analysis formula:
$K D=r^{2} x 100 \%$

with this additional information:

$\mathrm{KD}=$ determination coefficient

$\mathrm{R}=$ correlation coefficient

\section{RESULTS AND FINDINGS}

Waste is a rather complex problem not only because of the increasing volume of litter with increasing population, limited transportation has caused people to be unable to accommodate the final landfill. Domestic waste is waste that stems from everyday domestic activities that does not include specific excrement and litter. Waste management system in Kelurahan Maleer is directly carried out by people in that area where handspring and wadding is the first stage of waste management with the intent to prevent waste from being strewn and facilitating the collection process. Generally, waste production is dominated by domestic waste and others household activities and by means required good treatment against being a source of breeding for the variant of disease (by flies, cockroaches, and rats) which actually brings out the negative effects on the people on Kelurahan Maleer.

The problem with waste management in Kelurahan Maleer Bandung is related with waste management resources, financing constraints, behavior and lack of public awareness about waste management, the facility and infrastructure. Therefore, waste management activities should be done safely at the house level by displaying the principle of reducing, recycling and reuse, in that way that does not harm public and environmental health. The availability and infrastructure of waste management in Kelurahan Maleer are mapped out by waste dumping patterns in trash bins, trans polls, deposited or burned, dumped into the open water channel. Waste management in Kelurahan Maleer Kecamatan Batununggal, Bandung city is conducted by RT (Rukun Tetangga) and cooperate with the city's sanitation department of Bandung for waste transportation to the landfills called TPA (Tempat Pembuangan Akhir). Moreover, in Maleer Indah housing in RW 03, waste management based on household is carried out by the community and cooperated with the sanitation services to transport the waste to the final disposal. Currently under efforts to collect waste through collection, In this study, researchers try to determine policy implementation variables $(\mathrm{X})$ in reference to four factors of policy implementation, specifically: communication, sources, dispositional attitude and bureaucracy structure, with examination of 11 (eleven) indicators applied to the respondents answers possible answers to be selected and considered according to the respondents statements. The overall answer with a 5 (five) result for the local government policy implementation $(\mathrm{X})$, when described in the diagram can be seen the results of the overall research of policy implementation (X) as follows: 
Table III. Recapitulation of the local government

\begin{tabular}{lll}
\multicolumn{4}{c}{ policy implementation variables $(\mathrm{X})$} \\
\hline Factors & $\begin{array}{l}\text { Implementation of The Local } \\
\text { Government Policy }\end{array}$ \\
\hline Communication & $\mathbf{6 3 . 1 7 \%}$ \\
\hline Resources & $64.18 \%$ \\
\hline Attitudes & $60.87 \%$ \\
\hline Bureaucracy & $60.11 \%$ \\
Structures & & \\
\hline
\end{tabular}

Based on the recap result from above, it shows from 4 (four) factors filed for policy implementation variables (X) on first factors are communication gets the high value impact is as much $63.17 \%$, and for the second factors are resources get the smallest value impact it's $64.18 \%$ and the dimension of Attitudes (attitudes of implementor) gets value $60.87 \%$, and bureaucracy structures getting value $60.11 \%$. According to the criteria for measurement based on the overall percentage when measured would be $62.08 \%$, it's means the local government in Kelurahan Maleer Kecamatan Batununggal Bandung has not yet fully implemented, there are four factors of policy implementation that work concurrently and interrelate with each other in order to help and implement the policy. The ideal approach is to reflect the complexity with these 4 (four) factors is communication, resources, attitudes, and bureaucracy structures.

The overall answer to the variable (Y) the effectiveness of waste management program based on household needs in Kelurahan Maleer Kecamatan Batununggal Bandung, as illustrated in the table, the results of the overall research as follow:

Table IV. Recapitulation of The Effectiveness Waste Management Program Based on Household Needs Variable (Y)

\begin{tabular}{lccc}
\hline & Adaptation & Integration & $\begin{array}{l}\text { Goal } \\
\text { Achievement }\end{array}$ \\
\hline $\begin{array}{l}\text { The effectiveness } \\
\text { Waste }\end{array}$ & & \\
Management & & & \\
Program Based & $57.99 \%$ & $60.00 \%$ & $61.11 \%$ \\
on Household & & & \\
Needs Variable & & & \\
\hline
\end{tabular}

Based on the recapitulations results above, it shows from 3 (three) dimensions submitted on the effectivity of household needs-based waste management program, for goal achievement have the highest value is $61.11 \%$, the dimensions of integration value are $60 \%$, and the dimension of adaptation have value $57.99 \%$.

It's means KSM SALING ASIH (Kelompok Swadaya Masyarakat Sadar Lingkungan Asri dan Bersih) in Kelurahan Maleer haven't completely carried out the waste management policy as set forth in the regulation of local government number 9 of 2011 about waste management. The orientation in this research on largely effectiveness and in part ultimately depends on achieving the goal. Refers to the problem-solving theory above, the implementation of waste management program based on household needs in Kelurahan Maleer Kecamatan Batununggal Bandung city through goal achievement, integration, and adaptation can be effective.
The hypotheses suggested in this study, there is significant influence or impact between independent variables (the implementation of local government policy) with dependent variables (the effectivity of waste management based on household needs). For the hypotheses test is with $\mathrm{F}$ test. Before doing the hypotheses test, simple regression analysis and determination of coefficient analysis that has been done.

4.1 Simple Regression Analysis

This analysis is for to measure the impact or influence variable with other variables, it's the implementation of local government policy impact with the waste management program based on household needs effectivity. The results with software SPSS 21 are the regression coefficient value $(\beta)$ for each variable in this study.

Table V. Coefficients ${ }^{\text {a }}$ (stand for dependent variable: waste management)

\begin{tabular}{crrcll}
\hline \multicolumn{7}{c}{ Unstandardized Coefficients } & $\begin{array}{l}\text { Standardized } \\
\text { Coefficients }\end{array}$ \\
Model & \multicolumn{7}{c}{ B } & Std. Error & \multicolumn{1}{c}{ Beta } & \multicolumn{1}{c}{ T Sig. } \\
1 (Constant) & -3.394 & 2.163 & & -1.569 & .119 \\
Policy & .793 & .059 & .765 & 13.370 & .000 \\
Implementation & & & & & \\
\hline
\end{tabular}

As for the interpretation of the above regression equation is as follows: (1) The effectiveness of waste management of household-based value of -3.394 Unit on the implementation of the policy of 0. (2) Each implementation of the policy of local Governments increased by 1 unit, then the effectiveness of waste management -based Household increased 0.793 unit.

4.2 The Determination of Coefficient

To determine the extent of the independent variable on dependency variables, a coefficient determination must be test to look for the value of $r^{2}$ The value of $r^{2}$ is used to measure the total variable proportion or presentation in dependent variable $(\mathrm{Y})$ described by independent variables $(\mathrm{X})$. in this study, the $\mathrm{r}^{2}$ value shows the enormous impact the local government policy implementation has on the effectiveness of household needs-based waste management program simultaneously. The determination of coefficient in this study can be seen in table VI.

Table VI. Determination Coefficient Model Summary

\begin{tabular}{llrrr}
\hline Model & \multicolumn{1}{c}{ R } & R Square & \multicolumn{1}{c}{$\begin{array}{c}\text { Adjusted R } \\
\text { Square }\end{array}$} & \multicolumn{2}{c}{$\begin{array}{c}\text { Std. Error of the } \\
\text { Estimate }\end{array}$} \\
1 & $.765^{\text {a }}$ & .585 & .581 & 5.19885 \\
\hline
\end{tabular}

a stand for policy implementation

b stands for the waste management program based on household needs effectivity

According to the table above it that $\mathrm{r}^{2}$ value 0.585 , there is a $58.5 \%$ of impacts between the local government policy implementation and the effectivity of waste management program based on household needs. Whilst the other impacts excluded from the study is as high as $41 \%$. 


\section{CONCLUSION}

Based on the findings it is known that with the F test it's known how much the implementation of local government policy affects the waste management program based on household needs. In the calculations scored the value of regression coefficient $(\beta)$ for a variable effectiveness of waste management program based on household needs is worth -3.394 units in policy implementation by 0 . Each of policy implementation increases 1 unit, so the effectiveness of waste management program based on household needs increases 0.793 units. To see the magnitude of the local government's policy implementation to the effectiveness of waste management program based on household needs simultaneously, there is a $58 \%$ of impacts between the local government's policy implementation and the effectivity of waste management based on household needs. Whilst the other impacts excluded from the study is as high as $41 \%$. Therefore, there is a significant association between the local government's policy implementation and the effectivity of household needs-based waste management in Bandung city.

\section{REFERENCES}

1. P. Daerah (n.d.), Peraturan Daerah Kota Bandung Nomor 09 Tahun 2011 Tentang Pengelolaan Sampah. Bandung: Local Government.

2. W. N. Dunn, Pengantar Analisis Kebijakan Publik. Yogyakarta: Gadjah Mada University Press, 2000.

3. G. C. Edwards III, Implementing Public Policy. Washington: Congressional Quartley Press, 1980.

4. A. Hoogerwerf, Ilmu Pemerintahan. Jakarta: Penerbit Erlangga, 1990.

5. R. Indonesia (n.d.), Peraturan Daerah Kota Bandung Nomor 09 Tahun 2011 Tentang Pengelolaan Sampah. Bandung: PEMKOT Bandung.

6. R. Indonesia (n.d.), Peraturan Pemerintah No.73 Tahun 2005 Tentang Kelurahan. Jakarta: Central Government.

7. R. Indonesia (n.d.), Undang-Undang Nomor 18 Tahun 2008 Tentang Pengelolaan Sampah. Jakarta: Central Government.

8. R. Indonesia (n.d.), Undang-Undang Nomor 8 Tahun 2008 Tentang Pengelolaan Sampah. Jakarta: Government.

9. I. Islamy, Prinsip-prinsip Perumusan Kebijaksanaan Negara. Jakarta: Bumi Aksara, 1997.

10. A. Leo, Politik dan Kebijakan Publik. Bandung: AIPI, 2006.

11. R. M. Steers, Efektivitas Organisasi. Jakarta: Penerbit Erlangga, 1985.

12. S. Pamudji, Kepemimpinan Pemerintahan di Indonesia. Jakarta: Bumi Aksara, 1995.

13. M. R. Rasyid, Makna Pemerintahan: Tinjauan dari Segi Etika dan Kepimpinan. Jakarta: PT Yarsif Watampone, 1997.

14. M. Singarimbun, Metode Penelitian Survey. Jakarta: LP3ES, 1995.

15. Sugiyono, Metode Penelitian Administrasi. Bandung: CV Alfabeta, 2006.

16. H. Tachjan, Implementasi Kebijakan Publik. Bandung: AIPI, 2006.

17. S. A. Wahab, Analisa Kebijakan dari Formulasi ke Implementasi Kebijakan Negara. Jakarta: Bumi Aksara, 2001.

18. Walikota. (n.d.), Instruksi Walikota Bandung No. 002 Tahun 2013 Tentang Rencana Aksi Menuju Bandung Juara, Bandung: Pemerintah Kota.
19. B. Winarno, Kebijakan Publik: Teori, Proses, dan Studi Kasus: Edisi dan Revisi terbaru. Yogyakarta: Center for Academic Publishing Service (CAPS), 2012.

\section{AUTHORS PROFILE}

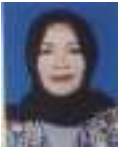

Emi Rachmawati, Dra., M.Si., Finished my formal Education, both graduate and post graduate program in the Langlangbuana University, major in Governmenta Sciences. And since the 90's I dedicated myself as a lecturer in this institution. To enhance my ability as lecture and to enlarge my knowledge, I actively follow various educational professional training, and also active in a variety of research work such as recent research work on the controlling development innovation program and empowerment of territoriality (2018) and The implementation of voter data update policy at Electoral Commission in Bandung (2019). In addition to research work, I actively write publication in various social publication, such as recent one on SOSPOL Journal Vol. XXV 2018 and on Bunga Rampai 2nd Edition 2019. Other than research work and publication, as a member of civic society I actively participate in community engagement such as recent event, I was appointed as a guidance counselor for Posyandu personals (2019). I also engage in education organization in Indonesia and become one of its members, such as ADI and PDRI.

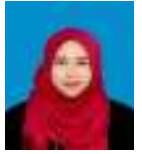

Dina Alamianti, S. Sos., M. I.Kom., Earned a Bachelor's in communication management at Bandung Islamic University and a Master's degree in communications at the University of Padjadjaran in 2011. Working as a lecturer at the University of Budi Luhur (2011), University of Garut for two years (2012-2014), and now as lecturer at communication program, under the Faculty of social science and political science in Langlangbuana University, since 2014. I teach many communication subjects, such as interpersonal Communication, public communication, and mass communication. Research ever undertaken and the publication of these past two years are phone snubbing and social interaction (2019), public policy communications (2018), as well as an Overview of Augmented Reality in the print media (2018). I participate as Guidance Counselor for College internship for social work in the village on Cangkuang, Garut (2016) and help the effort to village program such as its public services and waste management. I manage DIALEKTIKA and DIALOG Journal at the Langlangbuana University. As well as lecturers, I participate in the activities of professional organizations such as the PDRI (Union of the Republic of Indonesia Lecturer), ASPIKOM, and play a role in quality assurance at the University as Internal quality Auditors.

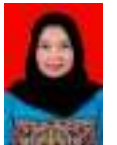

R Indriyati Kamil, S. IP. M.Si., Indonesia Nationality, born in Bandung on December 6, the year 1973. Once educated in the field of Public Administration and Communication at the University of Padjadjaran in Bandung. Work experience in survey research Indonesia (1996-1998), taught at the Padjadjaran Polytechnic (1999-2005), University of Sanggabuana (2005-2010), University of Langlangbuana Bandung (2002-until now). In addition to faculty, active in the Quality Assurance Unit (SPMU) University as Vice Chairman. Research activities and publications ever done of them is the role of the Government in handling communication environment of the slums (2018), the Role of the Environmental Communities in Kamojang Natural Java Natural Reservation (2018), optimization of the Social Responsibility by the Government for the area of the River in Bandung (2016), the role of Social Media in the embody Good Government (2013).

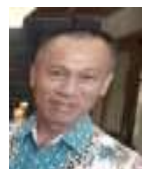

Ero Suhara, S. IP, M.Si. Born in Bandung on 13 September 1964. The Citizenship Status Of Indonesia. Educational experience in SD NegeriCikutral Kota Bandung (graduated 1979), SMPN19Bandung (1982), SPGN2 Bandung (1985) , S-1 POLITICAL SCIENCE Majors, at Langlangbuana University Bandung (1998), S-2 Master degree Government Science at UNLA Bandung (2007). Experience the work of teaching remains at Governance Program on Faculty of social and Political Sciences in Langlangbuana University Bandung (UNLA) since the year 2000 until now. Research and experience Papers: research and Study the establishment of a Regency Ogan Ilir South Sumatra Province Year 2006, 
preparation of Structural Organization Office Competency Standards West Bandung Regency Region devices 201, preparation of the Organization's Workload Device Majalengka Regency Area 2011, Team Study Changes the Status of the administrative Villages in the 2014 Review Team Setup, a village in 2014, Control of street vendors in the area of Cicadas Bandung 2018 and the coordination of Creative economic development in district Regol Bandung 2019. The experience of the Organization as a member of the PERSADI area of West Java, Indonesia Lecturers Association members (ADI), member in Republic of Indonesia Lecturers Union (PDRI), a member of the unity of the Indonesia Government study Program, a member of the Association of science courses The Government Of Indonesia.

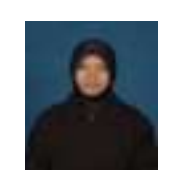

Dr. Wa Ode Nurul Yani, women who were born in Bandung on 28 March 1967, was married and had three daughters. Completed doctoral program with environmental communication studies in the Faculty of communication sciences Padjadjaran University in Bandung, Indonesia. Current profession as a Lecturer and Chair of the communication studies program at the Faculty of social science and political science University Langlangbuana Bandung. In the development of research communications, became editor in Chief of the Journal of Dialectics and dialogue. In the community, is currently a volunteer at mother and child Foundation, became a counselor for adolescents broken home and became tutor to the teenage dropouts. Used to work as: an announcer and Programmer in Radio FM Bandung MGT; be the MC, motivators and the leadership of the KCP in PT Bank Central Asia, Bandung; Volunteers in Environmental Spacecraft and YLKI (Walhi); and lecturer in several universities in Bandung. The philosopher who inspire: Jürgen Habermas. Hobbies reading philosophy books. E-mail address: yaniwaodenurul@gmail.com 